\title{
Table of treaties and international documents
}

African Charter on Democracy, Elections and Governance ............................ 235

Charter of the International Military Tribunal for the Far East ............................ 91

Charter of the International Military Tribunal of Nuremberg ................................ 91

Constitutive Act of the African Union, Jul. 11, 2000, 2158 U.N.T.S. 3 .............. 189

Convention Against Torture and Other Cruel, Inhuman, or Degrading Treatment or Punishment, Dec. 10, 1984, 108 Stat. 382, 1465 U.N.T.S. 85 ... 29, 177, 179,

Convention on the Prevention and Punishment of the Crime of Genocide, Dec. 9, 1948, 78 U.N.T.S. 277 $29,177-178,222$

Draft Code of Crimes against the Peace and Security of Mankind ...................... 92

G.A. Res. 57/228B, U.N. Doc A/RES/57/228B (May 13, 2003) ............................ 4

Geneva Convention Relative to the Protection of Civilian Persons in Time of War, Aug. 12, 1949, 6 U.S.T. 3516, 75 U.N.T.S. 287

International Convention on the Suppression and Punishment of the Crime of Apartheid, Nov. 30, 1973, 1015 U.N.T.S. 244, entered into force July 18, 1976.

International Covenant on Civil and Political Rights, Dec. 19, 1966, S. Treaty Doc. No. 9S-2, 999 U.N.T.S. 171 ............................................................... 221

International Covenant on Economic, Social and Cultural Rights, Dec. 16, 1966, 993 U.N.T.S. 3

Peace Agreement Between the Government of Sierra Leone and the Revolutionary

United Front of Sierra Leone

Protocol Relating to the Establishment of the Peace and Security Council of the

African Union, AU Assembly, 1st Ordinary Sess., Jul. 9, 2002

Protocol to the African Charter on Human and Peoples' Rights on the

Establishment of the African Court on Human and Peoples' Rights,

Status of Ratifications

S.C. Res. 827, U.N. Doc. S/RES/827 (May 25, 1993) ......................................... 4

S.C. Res. 1313, U.N. Doc. S/RES/1313 (Aug. 4, 2000) ....................................... 4

S.C. Res. 1503, U.N. Doc. S/RES/1503 (Aug. 28, 2003) ................................... 74

United Nations Charter ............................................................................... 216

Universal Declaration of Human Rights, G.A. Res. 217 (III) A, U.N. Doc. A/RES/

217(III) (Dec. 10, 1948) .................................................................. 218

Vienna Convention on Consular Relations, Apr. 24, 1963, 596 U.N.T.S. 261 ....... 71

Vienna Convention on Diplomatic Relations, Apr. 18, 1961, 500 U.N.T.S. 95 ..... 71

Vienna Convention on the Law of Treaties (VCLT), May 23, 1980, 1155 U.N.T.S. 331 


\section{STATUTES, RULES AND REGULATIONS OF INTERNATIONAL/HYBRID COURTS}

Agreement between the Government of the Republic of Senegal and the African Union on the Establishment of Extraordinary African Chambers within the Senegalese Judicial System $9,10,12$

Agreement between the International Criminal Court and the Government of the Kingdom of Belgium on the Enforcement of Sentences of the International Criminal Court, ICC-PRES/06-01-10 (Jun. 1, 2010) 86

Agreement between the International Criminal Court and the Government of the Republic of Finland on the Enforcement of Sentences of the International Criminal Court, ICC-PRES/07-01-11 (Apr. 24, 2011) 86

Agreement between the United Nations and the Royal Government of Cambodia concerning the Prosecution under Cambodian Law of Crimes Committed During the Period of Democratic Kampuchea

Agreement between the United Nations and the Lebanese Republic on the

Establishment of a Special Tribunal for Lebanon

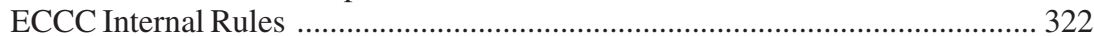

ICC Regulations of the Court, ICC-BD/01-02-07 (Dec. 18, 2007) .................... 277

ICC Rules of Procedure and Evidence ........................................................... 276

ICTR Rules of Procedure and Evidence ........................................................... 292

ICTY Rules of Procedure and Evidence ..................................................... 292

Law on the Establishment of the Extraordinary Chambers ............................ 9-10

On the Establishment of Panels with Exclusive Jurisdiction Over Serious Criminal

Offenses, United Nations Transitional Administration in East Timor,

UNTAET/REG/2000/15

Rome Statute of the International Criminal Court, U.N. Doc. A/Conf. 183/9

(1998) 5, 7, 9-11, 13-15, 17, 19-20, 24-27, 30, 36, 54, 59-62, 158, 173, $188,197,201,213,269,271$

SCSL Rules of Procedure and Evidence 308

Special Tribunal for Lebanon, Rules of Procedure and Evidence ............. 82-83, 97

Statute of the International Criminal Tribunal for Rwanda, S.C. Res. 955, U.N. Doc. S/RES/955 (Nov. 8, 1994) 9, 12, 14, 73, 76, 92, 292

Statute of the International Criminal Tribunal for the Former Yugoslavia, S.C. Res.

827, U.N. Doc. S/RES/827 (1993) 9-12, 14, 73, 76, 92, 292

Statute of the Special Court for Sierra Leone …..................... 9-10, 12, 14, 78, 92

Statute of the Special Tribunal for Lebanon, S.C. Res. 1757, U.N. Doc. S/RES/1757 (2007)

$10,12,14$

\section{NATIONAL CONSTITUTIONS AND STATUTES}

Algeria Law 68-697 of July 31, 1968

Argentina Constitution of the City of Buenos Aires (1996) ................................ 189

Brazil Law n6.683/79 (1979) .................................................................... 148

Central African Republic Amnesty Law (2008) ................................................. 189

Côte D'Ivoire Constitution .......................................................................... 152 
Lomé Agreement

Panama Executive Decree No. 2, January 18, 2001

Spain Law 22.924 of September 22, 1983

Truth and Reconciliation Commission Act 2000 (Sierra Leone)

Uganda Amnesty Act

32

Uganda Amnesty (Amendment) Act

32

Uruguay Law on Cooperation with the ICC 
Linda E. Carter, Mark Steven Ellis, and Charles C. Jalloh - 9781784719821 Downloaded from PubFactory at 04/26/2023 05:44:36AM 